\title{
The Influence Of Personal Factors, Organizational Factors, And Technological Factors In The Use Of CIM Toward Employees Knowledge Sharing In PT. Jalan Tol Lingkar Luar Jakarta (Pt. JLJ)
}

\author{
Bimantoro Kushari Pramono \\ Telkom University \\ Bandung, Indonesia \\ bimantorokushari@rocketmail.com
}

\author{
Ade Irma Susanty \\ Telkom University \\ Bandung, Indonesia \\ adeirma@telkomuniversity.ac.id
}

\begin{abstract}
This study aimed to acknowledge how big is the personal, organization, and technological factors, and moreover to acknowledge how deep is the effect influenced by personal, organization, and technological factors in the use of CIM towards employee's knowledge sharing in PT. Jalan Tol Lingkar Luar Jakarta. The study involved independent and dependent variables. The independent variables used in this study were personal factor, organization factor, and technological factor. While the dependent variables used was knowledge sharing. Research method used in this study was quantitative research and the type of this study were descriptive and causal study. Data analysis technique used were descriptive analysis and multiple linear regression. The descriptive analysis showed that PT. JLJ have big factors on personal, organization, and technological

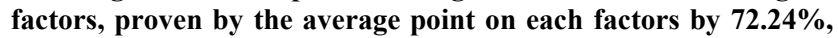
$\mathbf{7 4 . 7 7 \%}, \mathbf{7 2 . 9 8 \%}$ and also have a high point on sharing knowledge by average $77.11 \%$. Simultaneously, the personal, organization, and technological factors influenced significantly towards knowledge sharing by $\mathbf{4 5 . 3 \%}$. Partially, only organization factor which have influence towards knowledge sharing by $30.6 \%$.
\end{abstract}

Keywords: Personal factor, organization factor, technological factor, knowledge sharing

\section{INTRODUCTION}

\section{A. Background}

Knowledges are the most useful resources in business today [1]. Kikoski [2] believed that in 21st century, organizational success is depend on knowledges the have and on how they use their knowledges. According to Jennex [2], knowledge management became an approach which enabled organizations to managed information and knowledge in better ways. With knowledge management, organizations would run efficiently, be able to give better service towards customers, more competitive, and always responsive towards changes. The point of the successfulness on knowledge management application is knowledge sharing or knowledge transfer [3;1]. Knowledge sharing, either it's the spontaneous, structured, or the unstructured one, was a vital thing towards companies' successfulness. According to Rodin et al.[3], the implementation of knowledge management could not be separated from knowledge sharing, where the will of sharing knowledges between individuals were needed and then from this individuals' knowledges would be stored as organization's knowledges. Individualism culture have to be left, information owned by individuals have to be shared to the colleagues in order to achieve organizational development. So that by the existence of knowledges sharing, new ideas are hoped to be created, especially in selling value, product's quality and performance.

With the development of information technology such as the existence of web 2.0, this knowledge sharing activities were not only happened directly (face-to-face) but also could be done through internet usage [4]. Moreover, web 2.0 was said to be a website which enabled the internet users to actively and directly participate in content creating or giving feedbacks from the writing posted by other people. One of the web 2.0 technology based media, which today has already have a lot of users, was weblog (commonly known as blog). It is a web which enabled the users to share their opinions, information, skills, experiences, and also giving feedbacks towards other people's writing. Looking at the technology development happened, PT. JLJ generated an website which facilitating its employees in creating contents or giving feedbacks towards other's writing named Corporate Internal Media or commonly known as CIM.

Wahlross [5] stated that there are few main factors which could affect someone to use weblog as a knowledges sharing media, which are the personal, organizational, and technological factors. Lin [5] have summarized the most unique aspects from those three factors. Based on individual or personal factor, most experts highlighted the importance of benefits expected, faith and experiences in utilizing the 
technology, for example, employees were motivated to share their knowledges when they thought it was worth the efforts. Organizational factor was based on management's role and organizational culture. Openness and organizational culture which were supported by the managers would make employees willing to share their knowledges. Next, technological factor was including the organizational Information and Communication Technology (ICT), such as intranet procurement or any other online devices.

With all efforts done by PT. JLJ to motivate its employee in using CIM to share their knowledges, and also because there is no research from PT. JLJ towards CIM as knowledge sharing media, the writer want to know on how the influence of personal, organizational, and technological factors towards CIM for knowledge sharing, this study is titled "THE INFLUENCE OF PERSONAL FACTORS, ORGANIZATIONAL FACTORS, AND TECHNOLOGICAL FACTORS IN THE USE OF CIM TOWARD EMPLOYEES KNOWLEDGE SHARING".

\section{B. Objectives}

According with the problems' definition, so the study about "THE INFLUENCE OF PERSONAL FACTORS, ORGANIZATIONAL FACTORS, AND TECHNOLOGICAL FACTORS IN THE USE OF CIM TOWARD EMPLOYEES KNOWLEDGE SHARING" is aiming to:

1) Define Personal Factor towards CIM usage for Knowledge Sharing.

2) Define Organizational Factor towards CIM usage for Knowledge Sharing.

3) Define Technological Factor towards CIM usage for Knowledge Sharing.

4) Define Knowledge Sharing of PT. JLJ's employee by using CIM.

5) Define the influence of personal, organizational, and technological factors in CIM usage towards Knowledge Sharing.

\section{LITERATURE STUDY}

\section{A. Knowledge}

Drucker [6] defined knowledge as information which change something or someone. It happened when the information become basic before taking actions, or when the information enabled someone or institutions to take different actions, more effective than the actions before. Davidson and Voss [6] stated that, in fact, managing knowledge is a way for organizations to manage their employees and how long they spent time to use information technology. According Rusli [7] knowledge is information that is contextual, relevant, and applicable, or information that can be used. Islam and Khan [8] define knowledge is the product of information. When information is analyzed, processed and placed in context, it becomes knowledge. Alavi and Leidner [8] define This knowledge as information possessed in the mind of individuals. Drucker [9] states knowledge has been characterized as the "only meaningful resource".

\section{B. Knowledge Sharing}

Tobing [6] explained that knowledge sharing / transfer is a wide opportunities' creation to learn towards each organization members so it could improve its competencies independently. According to Lin [1] knowledge sharing culture could be defined as social interaction which involved knowledge, experiences and skills exchange between employees for each departments in organization. Hoof and Ridder [1] defined various knowledge as individual process in exchanging their knowledge (tacit and explicit) and integrated to create new knowledges. According to Sharrat \& Ushoro [8] the term 'Knowledge Sharing (KS)' implied giving and accepting information which is framed in context with knowledges regarding sources. Davenport and Prusak [10] define Sharing knowledge is one of the processes in KM.

Hooff and Ridder [4] defined that "Knowledge Sharing is a process where each individuals exchanging their knowledges (Tacit knowledge and explicit knowledge)". This definition according to Hooff and Ridder implied that knowledge sharing behavior is consist of bringing (donating knowledge), and getting (collecting knowledge). Donating knowledge is a behavior of communicating intellectual capital owned to others. Collecting knowledge is a behavior to consult with other individuals regarding the intellectual capital owned by others.

\section{Factors Which Influenced Someone in Web 2.0 Usage for KS (Knowledge Sharing)}

Wahlross [5] stated that there are few main factors which could influence someone to use blog as media for knowledge sharing. The few factors stated are personal factor, organizational factor, and technological factor.

\section{1) Personal Factor}

Personal factors are the factors consist of benefit expected and cost, trust issues, experience and skill with technology, and understanding of responsibilities. Benefit as a key factor including personal interest and collective interest. Personal interest are included, for example, daily work facilitation and collective interest refer to usage or contribution towards work environment. On the other side, cost is referring to time and negative effects towards professional's image. Trust is referring to mistrust on social media contents as trusted sources, doubting on others misusing the collective information and doubting on whether or not the information is right or wrong.

\section{2) Organizational Factor}

Organizational factor is consist of managerial implication and organizational culture. Managerial implication including responsibilities in giving appropriate training, giving positive feedbacks appreciating contribution, participation, and the existence of guides on how to use social media tools. Organizational culture focusing on feedbacks and appreciating colleagues' contributions, participations, and collaboration 
level in and on every business units. Organizational hierarchy level is measured in term of employees' dependency in decision making and dependency in distributing time for new, different works.

\section{3) Technological Factor}

Technological factor is referring to social media tools used. The aspects we should be focusing on the technological factor is the ease of use from the social media used.

\section{Research Methodology}

Research methodology used in this study is a quantitative method with the type of method are descriptive and causal. Data analysis technique used were descriptive analysis and multiple linear regression. Descriptive analysis technique used to answer problems number $1,2,3$, and 4 , where to define how strong the personal, organizational, and technological factors, and also knowledge sharing in PT. JLJ. The multiple linear regression were used to define how big is the influence of personal, organizational, and technological factors in CIM usage towards knowledge sharing.

\section{RESUlt AND DiscUSSION}

\section{A. Responden Characteristic}

Respondents characteristic based on gender were dominated by males by $80 \%$ and females by $20 \%$. Based on age were dominated by respondents with age $\leq 24$ years old by $62 \%$. Based on education, it were dominated by respondents with high school diploma by $61 \%$. Based on the working period, it was dominated by respondents which already worked for $1-3$ years by $64 \%$.

\section{B. Simultaneous and Partial Hypothesis Test}

According to the calculation of hypothesis test, it could be concluded as following.

TABLE I. COEFFICIENT DETERMINATION RESUlT

\begin{tabular}{|c|c|c|c|c|}
\hline $\begin{array}{c}\text { Mode } \\
1\end{array}$ & $\mathrm{R}$ & R Square & $\begin{array}{c}\text { Adjusted R } \\
\text { Square }\end{array}$ & $\begin{array}{c}\text { Std. Error of } \\
\text { the Estimate }\end{array}$ \\
\hline 1 &, $673^{\mathrm{a}}$ &, 453 &, 435 &, 42872 \\
\hline
\end{tabular}

a. Predictors: (Constant), Faktor_Teknologi,

Faktor_Personal, Faktor_Organisasi

b. Dependent Variable: Knowledge_Sharing

According to the table 4.1, it could be seen that the $\mathrm{R}$ square was $0.453=45.30 \%$. This value showed that the influence of personal factor, organizational factor, and technological factor towards knowledge sharing variable was $45.30 \%$ and the rest, $54.70 \%$ were influenced by other variables outside this study.
TABLE II. T TEST RESUlT

Coefficients $^{3}$

\begin{tabular}{|c|c|c|c|c|c|c|}
\hline \multirow[t]{2}{*}{ Mod } & & \multicolumn{2}{|c|}{$\begin{array}{c}\text { Unstandardized } \\
\text { Coefficients }\end{array}$} & \multirow{2}{*}{$\begin{array}{c}\text { Standardized } \\
\text { Coefficients } \\
\text { Beta }\end{array}$} & \multirow[t]{2}{*}{$\mathrm{t}$} & \multirow[t]{2}{*}{ Sig. } \\
\hline & & B & Std. Error & & & \\
\hline \multirow{4}{*}{1} & (Constant) & .963 & .273 & & 3,524 & .001 \\
\hline & Faktor Personal &, 145 &, 100 &, 138 & 1,446 &, 151 \\
\hline & Faktor_Organisa &, 434 & ,093 &, 475 & 4,676 &, 000 \\
\hline & $\begin{array}{l}\text { Faktor_Teknolog } \\
\mathrm{i}\end{array}$ &, 143 &, 083 &, 163 & 1,719 &, 089 \\
\hline
\end{tabular}

According to the table 4.2 above, it could be concluded that $\mathrm{t}$ value for each personal, organizational, and technological factor variables were 1.446, 4.676, and 1.719. Organizational factor were valued more that tables, which is 1.985. It means that only organizational factor which partially gave significant influence towards knowledge sharing. Organizational factor influencing knowledge sharing by $30.6 \%$. From the result, it could be concluded that the linear regression model for this study were $\mathrm{Y}=0,963+0,145 \mathrm{X} 1+$ $0,434 \mathrm{X} 2+0,143 \mathrm{X} 3$. This formula explained that if the employees did not have personal, organizational, and technological factor, then the knowledge sharing would be valued 0.936. When personal factor increased, then the knowledge sharing would increase too by 0.145 point. When organizational factor increased, then the knowledge sharing would increase too by 0.434 point. And also, when technological factor increased, then the knowledge sharing would increase too by 0.143 point.

Personal factor (X1), organizational factor (X2), and technological factor (X3) have significant influences simultaneously towards knowledge sharing by 0.453 or $45.3 \%$, while the rest were influenced by other factors outside the variables studied by 0.547 or $54.7 \%$. Partially, only organizational factor (X2) which significantly influencing the knowledge sharing, while personal factor (X1) and technological factor (X3) were not significantly influencing the knowledge sharing. The percentage of personal factor influence towards knowledge sharing was $30.6 \%$.

\section{CONCLUSION}

According to the test result, the conclusion for this study are following:

1) Personal factor on CIM usage towards PT. JLJ's employees was included on high category by $74.24 \%$

2) Organizational factor on CIM usage towards PT. JLJ's employees was included on high category by $74.77 \%$

3) Technological factor on CIM usage towards PT. JLJ's employees was included on high category by $72.98 \%$

4) Knowledge Sharing on CIM usage towards PT. JLJ's employees was included on high category by $77.11 \%$

5) According to the simultaneous and partial calculation, Personal factor (X1), organizational factor (X2), and 
technological factor (X3) on CIM usage towards knowledge sharing have significant influences, which would be explained as followed:

- Personal factor (X1), organizational factor (X2), and technological factor (X3) have simultaneous significant influences towards knowledge sharing by 0.453 or $45.3 \%$ while the rest were influenced by other factors outside this study by 0.547 or $54.7 \%$.

- Partially, only organizational factor (X2) which influenced significantly towards knowledge sharing while personal factor (X1) and technological factor (X3) did not significantly influenced the knowledge sharing. The percentage of personal factor influence towards knowledge sharing was $30.6 \%$

\section{References}

[1] A. I. Susanty, A. Wardhana, D. Hidayatunnisa, \& N. Auliya, "Extrinsic and Intrinsic Motivation Influence Employees Performance Through Knowledge Sharing", Proceedings of the International Conference on "Emerging Trends In Academic Research", 2014, pp. 446-454.

[2] R. Rodin, T. Kismiyati, \& T. Margono, "Implementasi Knowledge Sharing Sebagai Upaya Peningkatan Efektifitas Keprofesionalan Pustakawan (Studi kasus di Perpustakaan STAIN Curup)", Jurnal Pustakawan Online, 2015.

[3] A. R. Pradana, "Knowledge Sharing pada Community of Practice di PT. Pembangkit Jawa Bali, Unit Pembangkit Gresik", Journal Universitas Airlangga, Vol. 2, No. 1, 2013.

[4] S. Nurmahmudiyah, "Pengaruh Faktor Personal, Organisasi dan Teknologi Terhadap Penggunaan Blog Untuk Knowledge Sharing (Studi Eksplanatif Tentang Pengaruh Faktor Personal, Organisasi dan Teknologi terhadap Penggunaan Blog Civitas Academica Universitas Airlangga Sebagai Media Knowledge Sharing di Kalangan Mahasiswa)", Journal Universitas Airlangga, Vol. 2, No. 2, 2013.

[5] J. K. Wahlroos, Social Media as a Form of Organizational Knowledge Sharing, 2010, Retrieved from University of Helsinky's database.

[6] P. L. Tobing, "Knowledge Management: Konsep.arsitektur, dan implementasi. First edition, Yogyakarta: Graha Ilmu, 2007, ISBN: 978-9797-56210-6.

[7] Z. T. Alhalhouli, Z. B. Hj. Hassan, \& C. S. Der, "Factors Affecting Knowledge Sharing Behavior among Stakeholders in Jordanian Hospitals Using Social Networks", International Journal of Computer and Information Technology, Vol. 3, Issue 5, 2014, pp. 919-928.

[8] Md. S. Islam \& R. H. Khan, "Exploring the Factors Affecting Knowledge Sharing Practices in Dhaka University Library", Library Philosophy and Practice (e-journal), 2014.

[9] T. Papadopoulos, "Exploring the determinants of knowledge sharing via employee weblogs", International Journal of Information Management, Vol. 33, Issue 1, 2013, pp. 133-146.

[10]N. Md. Noor \& J. Salim, "Factors Influencing Employee Knowledge Sharing Capabilities in Electronic Government Agencies in Malaysia" International Journal of Computer Science Issues, Vol. 8, Issue 4, No 2, 2011 